The Medical

Renaissance of the Sixteenth Century

Edited by A. WEAR, R. K. FRENCH and I. M. LONIE

This book examines the relationship of medicine and the intellectual and social changes which took place in the Renaissance. The contributors describe how the whole range of medicine, from practical therapeutics to surgery, anatomy and pharmacy developed during this period.

$\$ 35.00$ net

\section{William Hunter and the Eighteenth-Century Medical World}

\section{W. F. BYNUM and ROY PORTER}

Arising out of a conference commemorating the 200th anniversary of the death of William Hunter (1718-1783), this book explores the career of that highly successful eighteenthcentury physician, obstetrician, medical educator, and man of culture against the backgrounds of the medical, intellectual, social, and medical-institutional worlds of his time. About \$27.50 net

Fortbcoming (November)

\section{The Cultural Meaning of Popular Science}

Phrenology and the Organisation of Consent in Nineteenth Century Britain

\section{ROGER COOTER}

This study of the popularity of phrenology in the second quarter of the nineteenth century concentrates on the social and ideological functions of science during the consolidation of urban industrial society. It is influenced by Foucault, by recent work in the history and sociology of science, by critical theory, and by cultural anthropology.

$\$ 25.00$ net

Cambridge History of Medicine
Madness, Morality and Medicine

A Study of the York Retreat, 1796-1914

ANNE DIGBY

This detailed study of the York Retreat (famous for promoting mild methods of treatment for the insane) uses for the first time the unrivalled wealth of archival material on the Retreat's history and is thus able to tackle the complexities of the development of psychotherapy in the nineteenth century. An examination of the personal papers of a Retreat attendant provides rare insight into the attitudes of those who cared for the insane in Victorian England.

$\$ 27.50$ net

Cambridge History of Medicine

\section{Hospital Life in Enlightenment Scotland GUENTER B. RISSE}

This is the first complete account of life in an eighteenth-century British hospital. Using a multitude of surviving documents, the author presents an intimate view of the experiences of the sick poor and their physicians at the Royal Infirmary of Edinburgh between 1750 and 1800.

About $\$ 27.50$ net

Fortbcoming (December)

Cambridge History of Medicine

\section{Patients and Practitioners ROY PORTER}

The essays in this volume provide an unusual historical perspective on the experience of illness; they try to reconstruct what being ill (from a minor ailment to fatal sickness) was like in pre-industrial society from the point of view of the sufferers themselves. It is a very important work as almost no studies of this kind have ever been carried out before.

About \$30.00 net

Fortbcoming (January)

Cambridge History of Medicine 


\title{
The Journal of Medicine and Philosophy
}

\author{
Editor. EDMOND D. PELLEGRINO \\ Associate Editor: H. TRISTRAM ENGELHARDT, JR.
}

The Journal of Medicine and Philosophy explores the shared themes and concerns of philosophy and the medical sciences. Not since Galen's time has the contact between medicine and philosophy been so widespread; the Journal seeks to meet the challenge of this dialogue by providing a forum for philosophers, medical practitioners, educationists, and humanists to examine the problems and controversies stimulated by the engagement of these two disciplines.

\section{Some Recent Articles}

Ernan McMullin: Diagnosis by Computer. Hans-Martin Sass: Reichsrundschreiben 1931: Pre-Nuremberg German Regulations Concerning New Therapy and Human Experimentation. Fred Rosner: The Traditionalist Jewish Physician and Modern Biomedical Ethical Problems. Ronald M. Green: The Priority of Health Care. John C. Kunz et al: Computer-Assisted Decision Making in Medicine. Joan C. Callahan: Liberty Beneficience, and Involuntary Confinement.

\section{Subscription Information}

1985, Volume 10 (4 issues)

ISSN 0360-5310 Institutional rate: Dfl. $115,-/ \cup S \$ 44.00$ per volume incl. postage/ handling

Private rate: Dfl. 62,-/US $\$ 21.00$ per volume incl. postage/handling Private subscriptions should be sent direct to the publishers.

\section{REIDEL PUBLISHING COMPANY}

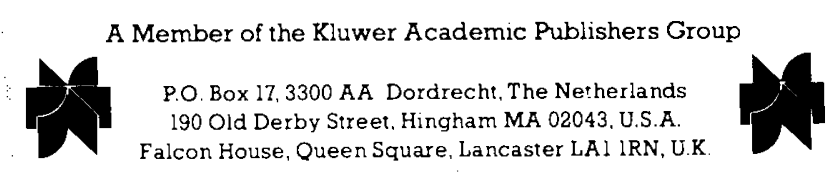




\section{MEDICAL BOOKS}

Prints * Portraits

\section{Old, RaRe,}

\& OUT-OF-Print

\section{America's Largest Stock}

All items are fully catalogued and classified. American and European. dating from the 15th to the 20th centuries particularly classical and unusual works. with emphasis upon history, biography, and specialized medicine.

Lists issued in all fields of medicine.

We are eager to purchase small or large collections.

\section{ARGOSY BOOK STORES}

116 E. 59th St., N.Y., N.Y. 10022, PL.3-4455
F. E.

Whitehart

40 Priestfield Rd.

Forest Hill

London SE23 2RS

01-699 3225
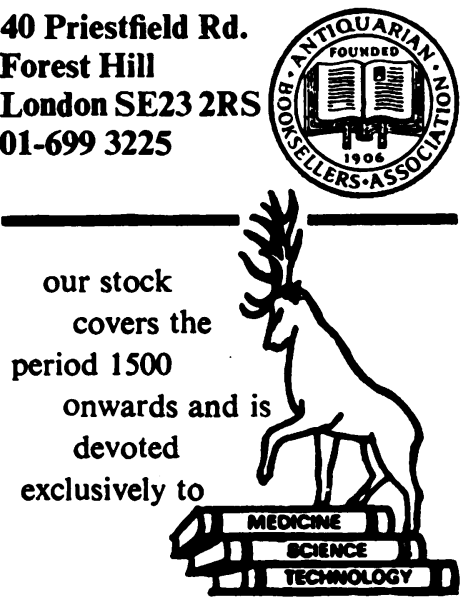

CATALOGUES ISSUED

Normal business hours or by appointment

Rare Books \& Manuscripts in the bistory of

Medicine \& the Sciences

BOUGHT $\cdot$ SOLD $\cdot$ APPRAISED

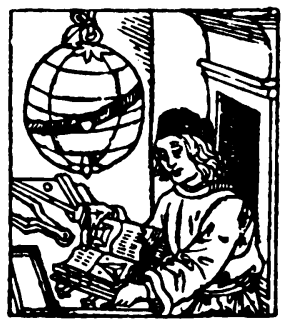

Send for our latest catalogue

Jeremy Norman \& Co., Inc.

$4+2$ POST STREET

SAN FRANCISCO, CALIFORNIA $9+102$

(415) $781-6+02$

\section{Ligiel Qhillips $_{\text {RAREBOOKS }}$}

Antiquarian books in the history of medicine and the health sciences.

Please send for my catalogue.

\section{RADCLIFFE SQUARE}

PUTNEY HILL

LONDON SW15 6BL

ENGLAND

Tel: 01-7882664 